\title{
REVEALING HISTORY THROUGH LYRICS: A STUDY ON CONTEMPORARY SELECT LYRICS IN TELUGU MOVIES
}

\author{
V.V. Subba Rao \\ Research Scholar, \\ Dept. of English, K L University \\ Vaddeswaram, Guntur Dist.A.P \\ Email ID : subbu_vv74@yahoo.com
}

\begin{abstract}
Every year the Hyderabad based Tollywood film industry produces several hundred movies and associated thousands of lyrics that collectively reflect the state and evolution of popular Telugu culture and Telugu language usage over last eight decades. Themes of those lyrics depend on the situation or atmosphere created in the film. There are a few poets who used this literary form as a weapon to remind the listener about history, culture, values of language and life style. The intention of those writers is to create awareness on greatness of the mother tongue and sweetness of vernacular. When the literary form is mixed with regional lingual fragrance, it got a widespread effect on the mind of the listener. The present paper titled: "Revealing History through Lyrics: A Study on contemporary select lyrics in Telugu movies" focuses on the literary study of the history and culture how it reflected in recent film lyrics. As the scope of the topic is so wide I limit myself to a critical study on three Telugu movie lyrics and how the epical, historical and philosophical backdrop is reflected in those lyrics. A comparative study on the western and Indian Telugu pattern of using lyrics in reflecting the history exhibits how lyric plays a critical role in enhancing literary values. In this paper I also observe a linguistic study of select Tollywood lyrics with recent techniques of complex network analysis. Naturally the substance of lyric poetry is universality and social in nature. One who hears the voice of mankind in the solitude of lyric understands what the lyric is saying. Sometimes even solitariness of lyrical language itself is prescribed by an individualistic and ultimately societal in its instinct depending upon the intensity of its individualization. That is the reason why reflection on the work of lyric is justified in inquiring and obligated to inquire concretely into social content but not with vague feelings of universal and inclusive. In order to susceptible of aesthetic contemplation, works of art must always be thought through lyrical poetry.
\end{abstract}

Key words: melody, lyric, culture, language, vernacular, film, linguistic study, aesthetic contemplation.

A set of words that make up a song consisting of verses and choruses are called Lyrics. The meaning of lyric is explicit or implicit but some times abstract and vague because of their explication on form, articulation, metre and symmetry of expression. It is not out of context if the history of lyric is explained in a bird's eye view. The word "Lyric" is derived from Greek via Latin which is a song accompanied by a musical instrument Lyre. First it 
ELK

Asia Pacific Journals

appeared in the first half of the $16 \mathrm{~h}$ century. The writer of lyric recollects a timeless period of introspection or memory in which he recounts his feelings, impressions and thoughts. The lyrics such as Beowulf or the Illiad are driven by the interactions of characters within a plotline of specific events occurring in a specific order. It is not out of context if a brief history of lyric from the wester point of view is discussed here. “ The New English Boys's Song about Thanksgiving Day", is a lyric written by Lydia Maria Child, is first appeared in Flowers for Children Volume 2 in 1844 which celebrated the childhood memories of visiting the Grandmother's House. This lyric set to a tune presented for Chirstmas. The line "Hurrah for Thanksgiving day" is associated with snow in November. The National Anthem of the United States of America, "The Star-Spangled Banner" is a lyric written in 1814 by 35 year old Lawyer Francis Scott Key after witnessing the bombardment during the Battle of Fort Mchenry in the War of 1812. This lyric was set to the tune of the popular British song Written by John
ELK Asia Pacific Journals - Special Issue

ISBN: 978-81-930411-1-6

Stafford Smith for the Anacreonitic Society, a men's social club in London. . Though the lyrics are rapid-fire with several people and events mentioned in a single word each, there is widespread agreement on the meaning of the lyrics. Steven Ettinger wrote, Billy Joel captured the major images, events, and personalities of this half-century in a three-minute song... It was pure information overload, a song that assumed we knew exactly what he was singing about...What was truly alarming was the realization that we, the listeners, for the most part understood the references.

The theme of the lyric transferred from patriotism and devotion to Social movement during Kent Students Movement. On May 4, 1970, a student demonstration at Kent State, "Ohio" left four students dead, one paralyzed, and eight others wounded. This demonstration, meant to be one of many peaceful demonstrations against the war, was ended abruptly and violently when the National Guard fired into the crowd for 13 seconds. The brief shootings ended the lives of students Jeffrey 
ELK

Asia Pacific Journals

Miller, Allison Krause, William

Schroeder, and Sandra Scheuer. The distances ranged from 270 feet to 390 feet. Some of these students were not even directly involved. Justified or not by self-defense, the "massacre" sparked a nationwide student strike that closed many colleges and universities. The lyric written during this period was quite popular still even now.

Even India, during the time of First War of Independence, there were so many lyrics written by unknown poets. Those lyrics were quite popular among the people. Surprisingly those are oral treasure of lyric written by unknown. During the time of independence movement, Vandemataram by Bankinchandra Chatterjii, "Vaisnava Jayatoo" lyric which was melodiously sung by $\mathrm{M} \mathrm{S}$ Subba Laxmi was very much attracted by Bapuji Mahatama Gandhiji. The National anthem of India “ Jana gana Mana" lyric created a havoc in the history of Indian Freedom struggle. It was influenced many regional poets to go for Lyrics. "Kollai Gatti ta ame" a lyric written on Gandhiji's principle of
ELK Asia Pacific Journals - Special Issue

ISBN: 978-81-930411-1-6

non violence was on the tip of the tongue to most of the freedom fighters during the period. Some of the regional poets used lyric form of poem for the purpose of revolution against the suppression made by Landlords in some of the places. "Bandenaka Bandi Katti" is a lyric written against the suppression made by cruel Nizam and atrocities made by the Razakars during the time of Talangana Arms Struggle movement. The intention of my presentation is to describe lyrical themes related to history in the recent films.

After six decades of Independence, the people started forgetting the historical background of their culture and tradition with the influence of Global culture. Everyone feels it fashion to be a fellow unknown of one's own culture. Most of the people feel shy to speak in their mother-tongue. Even it is butler; they try to speak in foreign language avoiding their own. To over come this pathetic situation, some of the native writers feel that film is the best media to create awareness on the culture, tradition and history of the country. They used Lyric as the best 
ELK

Asia Pacific Journals

suited literary form to change the atmosphere. As a result, now in film industry to introduce a lyric explaining the tradition, culture, history or something else is a fashion. Even people are quite fascinated to it also. Here I would like to observe a few Telugu Films for the support of my article. One among them is Adavi Ramudu (1977). The situation in the film is the protagonist went to a forest and looked at the pathetic situation of their life. He wanted to encourage the Tribal people by remembering their own traditional epic personality. The first poet, Valmiki is a Tribal man whose occupation is hunting for leading his life. One day he went to a forest for hunting. He shot at a bird that was sitting on a branch of tree and enjoying her romance with beloved. When it fell down, the other immediately jumped into the fire and sacrificed its life. It created tears in the eyes of the hunter. The tears turned him to tell the story of a great epic Ramayana. Next Eakalavya, the hero who is a stalwart in Archary, learn the art indirectly through a teacher named Drona. The story describes how the
ELK Asia Pacific Journals - Special Issue

ISBN: 978-81-930411-1-6

teacher deceived the student and supressed his talent in order to highlight his beloved student Arjuna. It also tells the story of Shabari who dedicated her life for the devotion of Rama. To expose this mythical event, the Writer Veturi Sundara Rama Murthy wrote a beautiful song “ Krushi Unte Manushulu Rushulautaru..." - hardwork is the only way to enhance man to divine.

The second lyric I would like observe in this context is Kiratarjuniyam written by Bharavi, a famous Sanskrit poet. The theme of the epic is taken from Vana Parva of the Mahabharata. During the time of the exile of Pandavas, suddenly Yudhistira, the Elder brother of Pandavas declare war over the Kauravas. In order to win the war, Arjuna, the middle one of the brothers, at the instruction of Indra propitiates of God Shiva with Penance in the forest. Pleased by his austerities, Shiva decides to reward Arjuna with Pashupataatra( a weapon of wonders). This transformed into mighty epic by Bharavi and it is very hard to understand even for learned people. But it is transformed into simple telugu by a simple lyric in the film 
ELK

Asia Pacific Journals

Bhakta Kannappa by Veturu Sundara

Rama Murthy. The work is known for its

brevity, depth (athmagauravam), and verbal complexity. At times, the narrative is secondary to the interlaced descriptions, elaborate metaphors and similes, and display of mastery in the Sanskrit language.

In the film Major Chandra Kanth (1993), the lyricist takes history to reveal the patriotism and devotion towards our nation. The time when people find no place to read history, the writer feel it is time to send a message that without history no country will develop any more. The wrtier Jalaadi takes historical legends like Shivaji, Katta Bammana, Subhash Chandra Bose and Alluri Sita Rama Raju and revealed their sacrifice to the nation's strength and liberation from clutches of Foreign Rulers. The rhyme, rhytham, melody, prosody that the writer used in the lyric gives inspiration to the listener free rendering of the story at ease.

Thus the lyric played a dominant role in reminding the history to the people in an affective manner. In the
ELK Asia Pacific Journals - Special Issue

ISBN: 978-81-930411-1-6

context of globalization, most of the people running behind the speed of the time, unknowingly forget their own history. The lyrics which I mentioned above where the writers with a sense of reminding history to the forgetting people, recollect once the greatness and sacrifice of their ancestors.

\section{References:}

[1] Over the River-A Turkey's Tale. Simon \& Schuster. 2005. ISBN 978-0-689-87635-6.

[2] Blackburn, Robin (1988). The Overthrow of Colonial Slavery, 1776-1848. Pp. 288-290.

[3] Billy Joel Q\&A: Tell Us About 'We Didn't Start The Fire?' University of Oxford, May 5, 1994

[4] Adaviramudu, Sundara Rama Murthy, 1976-77.

[5] Kiraatarjuneeyam, Bhakta Kannapa, Veturi , 1976.

[6] Majar Chandra Kanth, Jaladi, 1993. 